\title{
Multi-cycle Growth of Boron Doped ZnO Films as Photoanode for Dye-Sensitized Solar Cell (DSSC)
}

\author{
L. Roza, M.Y.A. Rahman ${ }^{*}$, A.A. Umar ${ }^{*}$, M.M. Salleh \\ Institute of Microengineering and Nanoelectronics (IMEN), Universiti Kebangsaan Malaysia (UKM), \\ Bangi, 43600, Selangor, Malaysia \\ *E-mail: mohd.yusri@ukm.edu.my, akrajas@ukm.edu.my
}

doi: $10.20964 / 2016.11 .32$

Received: 1 July 2016 / Accepted: 2 September 2016 / Published: 10 November 2016

The work is concerned with the fabrication of dye sensitized solar cell (DSSC) utilizing multi-layer boron doped $\mathrm{ZnO}$ nanorods films. The $\mathrm{B}$-doped $\mathrm{ZnO}$ films were prepared on FTO glass substrate via seed mediated hydrothermal method. Multi-layer B-doped $\mathrm{ZnO}$ nanorods were obtained by immersing the sample into a growth solution and repeated the growth process at $90{ }^{\circ} \mathrm{C}$ for 30 minutes. The structure of the B-doped $\mathrm{ZnO}$ film has been found to exhibit the hexagonal wurtzite structure. The length and diameter of the nanorods increase with the number of the growth cycle. The performance of the DSSC fabricated using the multi-layer B-doped $\mathrm{ZnO}$ nanorod was found to be significantly higher than that of the DSSC based on the single layer $\mathrm{ZnO}$ nanorod arrays. The best photovoltaic parameters with the $J_{\mathrm{SC}}$ of $3.5 \mathrm{~mA} \mathrm{~cm}{ }^{-2}, F F$ of 0.38 and $\eta$ of $0.67 \%$, respectively was obtained for the device utilizing the layer with 3 cycles since it possesses the lowest photoluminescence in visible region and lowest $R_{\mathrm{ct}}$.

Keywords: ZnO, boron, dye-sensitized solar cell, hydrothermal, nanorod

\section{$\underline{\text { FULL TEXT }}$}

(C) 2016 The Authors. Published by ESG (www.electrochemsci.org). This article is an open access article distributed under the terms and conditions of the Creative Commons Attribution license (http://creativecommons.org/licenses/by/4.0/). 